\title{
Sikap Warga Desa Ekowisata Pancoh terhadap Partisipasi Perempuan Pemilik Usaha Pariwisata Berdasarkan Pengukuran Women Owned Operated Tourism Businesses (WOOTB)
}

\author{
Anindwitya Rizqi Monica \\ Program Studi Pariwisata, Fakultas Ilmu Budaya, Universitas Gadjah Mada \\ Email: anindwitya@gmailcom
}

\begin{abstract}
This research aimed to understand resident's attitudes toward women participation in tourism businesses especially understanding potential impacts-based Women Owned and Operated Tourism Businesses (WOOTB) measurement. This research is being held in Pancoh Ecotourism Village, Turi, Sleman, Yogyakarta Special Region, Indonesia. WOOTB measurement created by Beedle (2011) through quantitative method. WOOTB is measured by six components. The components are tourism impact, tourism enhancement, economic enhancement, capacity building, community structure, and tourist contact. This measurement will seek for total score of each items from six components of WOOTB interpreted by scale that have been done by Umar (2001). By collecting the data from 100 residents from 15 - 64 years old, both who are involved and non-involved in tourism activities in Pancoh Ecotourism Village, the result shows that there are different attitudes from the residents. The difference shown from the average of total score in tourism impact component, economic enhancement component, and community structure component. Other than that, there is a similarity from the component of capacity building and tourism enhancement that revealed both high average to the statement by involved and non-involved residents. Meanwhile, in the component of tourism contact about "Women owned businesses in Pancoh would result in too much contact between local women and foreign tourists" revealed a low average to the statement both from involved and non-involved residents in Pancoh Ecotourism Village.
\end{abstract}

Keywords: Resident Attitudes, Women Participation, Tourism Businesses Women Ownership, Women Owned and Operated Tourism Businesses

\section{Pendahuluan}

Pariwisata selama beberapa tahun terakhir telah menjadi salah satu sektor yang berkembang dengan cepat di dunia. Terbukti pada tahun 2015 , sejumlah 1,2 miliar kedatangan wisatawan internasional telah berkontribusi sebanyak $10 \%$ atas kenaikan produk domestik bruto (PDB) dunia. Riset UNWTO (2011) memperlihatkan bahwa pertumbuhan pariwisata berpeluang pada penurunan kemiskinan dan pengembangan masyarakat. Meskipun demikian, masih sedikit perhatian dunia yang terarahkan pada ketimpangan ekonomi dalam pariwisata di antara

laki-laki dan perempuan, terkhusus pada negara berkembang. Riset tersebut memperlihatkan pula bahwa masalah perempuan yang terlibat dalam pariwisata masih terfokuskan pada beberapa stigma seperti perbedaan jenis kelamin, diskrimansi pekerjaan, pemberian status pekerjaan yang rendah dan pemberian upah yang rendah.

Perempuan dapat memegang peranan penting dalam pariwisata. Hal ini dibuktikan dari adanya partisipasi perempuan di sektor pariwisata. Badan Parwisata Dunia (2008) menyebutkan bahwa 
$60-70 \%$ pekerja dalam industri pariwisata dunia ialah perempuan. Pernyataan tersebut merupakan sebuah tolok ukur yang menyatakan bahwa sektor pariwisata membutuhkan peran perempuan. Salah satu penelitian yang mendukung pernyataan di atas ialah penelitian yang dilakukan oleh Chant dalam Sinclair (1997: 127-130) di Filipina dan Meksiko. Hasil penelitian tersebut memperlihatkan bahwa perempuan di negara Filipina dan Meksiko telah menjadikan sektor pariwisata sebagai sebuah pekerjaan. Meskipun demikian, peran perempuan dalam sektor pariwisata masih terbatas pada peran domestik. Alasan kuat itu dikarenakan perempuan tidak terlepas dari peran utama yaitu sebagai ibu rumah tangga. Hasil penelitian menunjukkan pula bahwa perempuan di Filipina dan Meksiko masih mendapati sikap yang bertentangan dari para suami dan masyarakat secara umum karena pekerjaan mereka yang dipandang mengganggu keselarasan rumah tangga, terkhusus dalam merawat anak. Pekerjaan tersebut juga mengondisikan perempuan berada pada status yang rendah dan upah kerja yang minim. Penelitian di atas memperlihatkan bahwa perspektif sikap masyarakat terhadap keterlibatan perempuan menjadi hal yang menarik untuk diteliti. Salah satu tujuan utama dari memahami sikap masyarakat adalah untuk mengembangkan pariwisata berkelanjutan, terkhusus pada aspek kemasyarakatan (Andereck dan Vogt, 2000: dalam Beedle, 2011: 23). Pemahaman sikap masyarakat tersebut berupa pengetahuan mengenai dampak positif dan dampak negatif dari adanya pengembangan pariwisata. Salah satu keuntungan dari meneliti sikap masyarakat ialah dapat membantu pemangku kepentingan dalam merencanakan pariwisata (Cukier dan Wall, 1993: dalam Beedle, 2011: 60).

Meskipun penelitian sikap masih sering disamakan dengan persepsi (Pickens, 2005: 53), namun, penelitian ini berbeda dengan penelitian persepsi. Perbedaan terletak pada fokus isi pernyataan dalam kuesioner yang lebih mengedepankan kecenderungan sikap khusus pada responden seperti baik, buruk, positif, negatif, setuju, atau tidak setuju pada suatu objek. Sedangkan pada penelitian persepsi terdapat sebuah proses interpretasi di mana responden dapat menyampaikan pandangannya terhadap suatu objek (Lindsay dan Norman, 1997: dalam Pickens, 2005: 53).
Dengan adanya penjelasan tersebut, penelitian mengenai sikap warga perlu dilakukan untuk memahami perspektif warga dalam memahami dampak-dampak potensial yang ditimbulkan dari keterlibatan perempuan dalam pariwisata (Beedle, 2011: 126). Salah satu desa wisata di Kabupaten Sleman yang menarik untuk diteliti ialah Desa Ekowisata Pancoh. Desa ekowisata yang terletak di Kecamatan Turi, Kabupaten Sleman.Selain pada lokasi penelitian yang menarik untuk diteliti, penelitian ini berfokus pada sikap warga di Desa Ekowisata Pancoh terhadap perempuan yang memiliki usaha pariwisata berdasarkan pengukuran yang diadopsi dari Women Owned and Operated Tourism Businesses (WOOTB). Desa Ekowisata Pancoh saat ini memiliki 29 usaha pariwisata yang diinisiasi, dimiliki, dan didukung oleh partisipasi perempuan untuk memenuhi kebutuhan wisatawan. Usaha tersebut berada pada penyediaan penginapan, warung makanan dan minuman, penjualan buah salak, dan suvenir salak. Hasil dari penelitian ini menjadi informasi dasar terkait perencanaan pariwisata melalui pemahaman sikap masyarakat, terkhusus pada pengembangan usaha pariwisata milik perempuan.

\section{Kerangka Teori}

Pariwisata dapat memberikan kesempatan bagi keterlibatan perempuan terkhusus pada wilayah pedesaan dan daerah berkembang lainnya. Melalui keterlibatan perempuan, dampak positif dapat dirasakan pada masyarakat meskipun terdapat tantangan dan konflik sosial terkait keterlibatan perempuan dalam kegiatan pariwisata (Beedle, 2011: 126).

Untuk mengetahui dampak-dampak potensial tersebut, Beedle (2011: 130) menunjukkan bahwa perlu adanya kajian mengenai sikap warga lokal terhadap partisipasi perempuan. Di antara berbagai kajian mengenai sikap warga lokal, Choi dan Murray (2010: dalam Beedle, 2011: 73) mengungkapkan bahwa memahami sikap warga merupakan hal yang krusial dalam memahami faktor-faktor yang memengaruhi perencanaan dan pengembangan pariwisata. Maka, sebelum melangkah ke tahap perencanaan dan pengembangan pariwisata, pemahaman sikap warga lokal terhadap partisipasi perempuan merupakan aspek yang penting untuk dikaji. 
Beedle (2011) merancang konsep untuk mengukur sikap warga terhadap partisipasi perempuan dalam usaha pariwisata dapat dilakukan secara kuantitatif menggunakan pengukuran Resident Attitudes towards Women Owned and Operated Tourism Businesses (WOOTB). Komponen dalam WOOTB ini dipilih dengan menggunakan instrumen survei yang berkaitan dengan skala item relevan dari studi-studi sebelumnya dan menggabungkan item yang berdasar pada literatur partisipasi perempuan dalam pariwisata. Uji instrumen menghasilkan pernyataan kuesioner sebanyak 22 buah dengan validitas dan reabilitas yang telah diuji oleh tenaga ahli di setiap konten pada item WOOTB (Beedle, 2011: 96). Komponen WOOTB terbagi menjadi enam, yaitu komponen dampak pariwisata, komponen peningkatan pariwisata, komponen peningkatan ekonomi, komponen peningkatan kapasitas, komponen struktur masyarakat, dan komponen kontak wisatawan.

\subsection{Komponen Dampak Pariwisata}

Komponen dampak pariwisata menitikberatkan pada eksplorasi sikap warga terhadap dampak pariwisata yang saling berkaitan antara dampak positif dan dampak negatif yang meliputi aspek ekonomi dan sosial budaya pada warga desa. Melalui WOOTB, Beedle (2011) mengadaptasi beberapa item yang memiliki relevansi dengan ekonomi dan kualitas hidup terhadap dampak potensial yang terjadi akibat pariwisata. Selain itu, WOOTB juga mengukur keterkaitan warga terhadap dampak sosial budaya dari adanya pengembangan pariwisata.

\subsection{Komponen Peningkatan Pariwisata}

Komponen peningkatan pariwisata adalah komponen yang melihat adanya keterlibatan perempuan sebagai produsen layanan pariwisata memiliki potensi untuk meningkatkan keberagaman dan kualitas pelayanan di lokasi-lokasi seluruh dunia (Beedle, 2011: 94). Scheyvens (2002: dalam Beedle, 2011: 94) menunjukkan bahwa dalam beberapa dekade terakhir sebuah pasar wisatawan yang berkembang mengarah untuk memelihara budaya telah banyak bermunculan.

\subsection{Komponen Peningkatan Ekonomi}

Peningkatan produk dan layanan wisata pada suatu daerah dapat memunculkan peningkatan pendapatan, baik pada tingkat individu maupun warga. Hal tersebut dapat merujuk pada peningkatan ekonomi di tingkat warga (Beedle, 2011:94). Peningkatan ekonomi tersebut juga tecermin dengan adanya multiplier effects dari penggunaan produk dan jasa lokal pada usaha pariwisata milik perempuan (Scheyvens, 2000: dalam Beedle, 2011: 94).

\subsection{Komponen Peningkatan Kapasitas}

Komponen sikap warga terhadap peningkatan kapasitas bertujuan untuk melihat adanya peningkatan kemampuan (skill) dalam bidang tertentu dan pendidikan (education) pada perempuan yang terlibat dalam usaha pariwisata. Peningkatan pendidikan dan keterampilan tersebut mencakup peningkatan pengetahuan perempuan dalam pemasaran pariwisata, bahasa, pemeliharaan lingkungan, dan pemeliharaan kebudayaan lokal yang berdampak positif pada warga (Beedle, 2011: 95).

\subsection{Komponen Struktur Masyarakat}

Struktur masyarakat adalah komponen yang bertujuan melihat ada atau tidaknya kelas-kelas sosial pada warga perempuan yang disebabkan oleh adanya usaha-usaha pariwisata yang dimiliki oleh perempuan. Intensitas perempuan dalam menekuni dunia pariwisata dapat berpengaruh pada persaingan antarkelompok perempuan lain yang sama-sama terlibat dalam pariwisata. Akibatnya, persaingan yang tidak sehat dapat menimbulkan konflik sosial pada kelompok-kelompok warga desa (Beedle, 2011: 95).

\subsection{Komponen Kontak Wisatawan}

Komponen ini didasari oleh adanya pandangan bahwa terdapat jumlah kontak yang diizinkan antara perempuan lokal dengan wisatawan yang digariskan oleh adat istiadat tradisional (Beedle, 2011: 95). Adanya kegiatan pariwisata membuat perempuan lokal harus berinteraksi dengan wisatawan asing sehingga kesempatan perempuan lokal untuk mengetahui kebudayaan lain dari wisatawan dapat berakibat pada perubahan budaya karena terlalu banyak berinteraksi dengan wisatawan asing. 


\section{Metodologi Penelitian}

Penelitian ini merupakan penelitian kuantitatif dengan menggunakan pendekatan deskriptif. Penelitian kuantitatif deskriptif ini memaparkan keadaan secara nyata dan apa adanya tanpa melihat hubungan-hubungan yang ada (Bungin, 2005:105). Teknik sampel yang digunakan ialah teknik sampel proporsional, yaitu teknik sampel yang dapat digunakan pada populasi berstrata, populasi area, ataupun populasi cluster (Bungin, 2005: 124). Dalam penelitian ini, diambil 100 responden warga yang terbagi menjadi dua kelompok responden, yaitu warga yang terlibat dalam kegiatan pariwisata dan warga yang tidak terlibat dalam kegiatan pariwisata. Tujuan pengelompokan responden tersebut ialah untuk melihat bagaimana perbedaan perspektif sikap warga dari masing-masing kelompok warga yang terlibat dan yang tidak terlibat dalam kegiatan pariwisata di Desa Ekowisata Pancoh.

Analisis data dilakukan dengan jawaban pada responden disesuaikan dengan skala likert dengan kode 1 (sangat tidak setuju), 2 (tidak setuju), 3 (netral), 4 (setuju), dan 5 (sangat setuju). Selanjutnya, dari hasil perkalian frekuensi dan masing-masing bobot diketahui jumlah skor total. Dalam analisis ini, sampel terbagi dari kelompok warga yang terlibat dalam kegiatan pariwisata yang berjumlah 72 orang dan kelompok warga yang tidak terlibat dalam kegiatan pariwisata yang berjumlah 28 orang. Analisis lebih lanjut penulis mengikuti ketentuan Umar (2001: 225-226) dengan formula rentang skala (RS) yang diperoleh sebagai berikut:

$$
R S=n \frac{(m-1)}{m}
$$

Keterangan:

$\mathrm{m}=$ jumlah alternatif jawaban tiap item

$\mathrm{n}=$ jumlah sampel

$$
\begin{gathered}
R S \text { warga terlibat }=72 \frac{(5-1)}{5}=72 \frac{4}{5}=57,6 \\
R S \text { warga tidak terlibat }=28 \frac{(5-1)}{5}=28 \frac{4}{5}=22,4
\end{gathered}
$$

Berdasarkan hasil penghitungan RS di atas, akan didapatkan interpretasi skala penilaian untuk warga yang terlibat dalam kegiatan pariwisata ialah
57,6 dengan minimal skor 72 dan warga yang tidak terlibat dalam kegiatan pariwisata ialah 22,4 dengan minimal skor 28. Selanjutnya, rentang skala untuk kelompok terlibat ditambah dengan 57,6 dan untuk kelompok tidak terlibat ditambah dengan 22,4 pada setiap kriteria di bawah ini.

Tabel 1. Interpretasi Skala Penilaian

\begin{tabular}{|c|c|c|}
\hline \multicolumn{2}{|c|}{ Skala Penilaian } & \multirow{2}{*}{ Kriteria } \\
\cline { 1 - 2 } $\begin{array}{c}\text { Terlibat dalam } \\
\text { Pariwisata }\end{array}$ & $\begin{array}{c}\text { Tidak Terlibat } \\
\text { dalam Pariwisata }\end{array}$ & \\
\hline $72-129,6$ & $28-50,4$ & $\begin{array}{c}\text { Sangat } \\
\text { Rendah }\end{array}$ \\
\hline $129,6-187,2$ & $50,4-72,8$ & Rendah \\
\hline $187,2-244,8$ & $72,8-95,2$ & Sedang \\
\hline $244,8-302,4$ & $95,2-117,6$ & Tinggi \\
\hline $302,4-360$ & $117,6-140$ & $\begin{array}{c}\text { Sangat } \\
\text { Tinggi }\end{array}$ \\
\hline
\end{tabular}

\section{Hasil Penelitian}

\subsection{Deskripsi Karakteristik Responden}

Mayoritas responden dalam penelitian ini (Tabel 2) merupakan responden yang berusia 55 - 64 tahun didominasi oleh reponden perempuan, berstatus menikah, telah menetap di Desa Ekowisata Pancoh selama lebih dari 20 tahun, dan memiliki latar belakang pendidikan terakhir di tingkat SMA.

\subsection{Penilaian Sikap Warga Terhadap Partisipasi Perempuan Pemilik Usaha Pariwisata Berdasarkan Pengukuran Women Owned and Operated Tourism Businesses (WOOTB)}

Tabel 3 memperlihatkan perbedaan baik warga yang terlibat dalam pariwisata maupun warga yang tidak terlibat dalam pariwisata di Desa Ekowisata Pancoh. Hasil skor total telah menunjukkan variasi yang terinterpretasikan dalam lima kategori yaitu sangat rendah, rendah, sedang, tinggi, dan sangat tinggi. Oleh karena itu, pada bagian ini akan ditunjukkan sikap warga terhadap perempuan pemilik usaha pariwisata di Desa Ekowisata Pancoh dinilai melalui hasil skor total masing-masing pernyataan pada enam komponen Women Owned and Operated Tourism Businesses (WOOTB) yang telah diinterpretasikan oleh skala Umar (2001: 225). 
Tabel 2. Karakteristik Responden

\begin{tabular}{|c|c|c|}
\hline Karakteristik & $\mathrm{n}$ & $\%$ \\
\hline $\begin{array}{l}\text { Usia } \\
15-24 \text { tahun } \\
25-34 \text { tahun } \\
35-44 \text { tahun } \\
45-54 \text { tahun } \\
55-64 \text { tahun }\end{array}$ & $\begin{array}{c}24 \\
8 \\
17 \\
24 \\
27\end{array}$ & $\begin{array}{c}24 \% \\
8 \% \\
17 \% \\
24 \% \\
27 \%\end{array}$ \\
\hline $\begin{array}{l}\text { Jenis Kelamin } \\
\text { Laki-Laki } \\
\text { Perempuan }\end{array}$ & $\begin{array}{l}37 \\
63\end{array}$ & $\begin{array}{l}37 \% \\
63 \%\end{array}$ \\
\hline$\frac{\text { Status Pernikahan }}{\begin{array}{c}\text { Belum Menikah } \\
\text { Menikah }\end{array}}$ & $\begin{array}{l}27 \\
73\end{array}$ & $\begin{array}{l}27 \% \\
73 \%\end{array}$ \\
\hline $\begin{array}{l}\text { Durasi Tinggal } \\
<5 \text { Tahun } \\
5-10 \text { Tahun } \\
10-15 \text { Tahun } \\
15-20 \text { Tahun } \\
>20 \text { Tahun }\end{array}$ & $\begin{array}{c}4 \\
9 \\
9 \\
18 \\
60\end{array}$ & $\begin{array}{c}4 \% \\
9 \% \\
9 \% \\
18 \% \\
60 \%\end{array}$ \\
\hline $\begin{array}{c}\text { Pendidikan Terakhir } \\
\text { SD } \\
\text { SMP } \\
\text { SMA/K } \\
\text { DIPLOMA III } \\
\text { STRATA } 1\end{array}$ & $\begin{array}{c}18 \\
16 \\
54 \\
5 \\
7\end{array}$ & $\begin{array}{c}18 \% \\
16 \% \\
54 \% \\
5 \% \\
7 \%\end{array}$ \\
\hline $\begin{array}{c}\frac{\text { Terlibat dalam Pariwisata }}{\text { Ya }} \\
\text { Tidak }\end{array}$ & $\begin{array}{l}72 \\
28\end{array}$ & $\begin{array}{l}72 \% \\
28 \%\end{array}$ \\
\hline
\end{tabular}

4.3. Perbedaan Sikap Warga Terlibat dan Tidak Terlibat dalam Kegiatan Pariwisata Terhadap Partisipasi Perempuan Pemilik Usaha Pariwisata Berdasarkan Pengukuran Women Owned and Operated Tourism Businesses (WOOTB) di Desa Ekowisata Pancoh

Setelah dieksplorasi secara menyeluruh melalui tabel 3, tabel 4 di atas menunjukkan beberapa perbedaan rata-rata setiap komponen antara warga yang terlibat dan tidak terlibat dalam kegiatan pariwisata di Desa Ekowisata Pancoh. Perbedaan sikap itu berada pada komponen dampak positif pariwisata, komponen peningkatan ekonomi, dan komponen struktur masyarakat. Pada warga yang terlibat dalam kegiatan pariwisata, hasil rata-rata menunjukkan kategori tinggi, yaitu 299,6. Akan tetapi, pada warga yang tidak terlibat dalam kegiatan pariwisata, hasil rata-rata menunjukkan kategori sedang, yaitu 95. Apabila melihat penelitian yang dilakukan oleh Beedle (2011: 107), komponen dampak positif pariwisata memperoleh hasil rata-rata dengan kategori tinggi. Hasil tersebut mengindikasikan adanya persamaan sikap warga terlibat di penelitian ini dengan penelitian Beedle (2011:107) yang mendukung sisi positif dari partisipasi perempuan pemilik usaha pariwisata. Berbeda dengan warga yang tidak terlibat di Pancoh, sikap mereka terhadap dampak positif pariwisata cenderung bervariasi. Hal ini menunjukkan adanya sikap warga yang setuju, tidak memihak, dan bahkan tidak setuju terhadap dampak positif dari partisipasi perempuan pemilik usaha pariwisata.

Tabel 3. Sikap Warga Desa Ekowisata Pancoh terhadap Partisipasi Perempuan Pemilik Usaha Pariwisata Berdasarkan Pengukuran WOOTB

\begin{tabular}{|c|l|c|c|c|c|}
\hline \multirow{2}{*}{ No } & \multicolumn{2}{|c|}{ Kernyataan } & \multicolumn{2}{c|}{$\begin{array}{c}\text { Terlibat dalam } \\
\text { Pariwisata }\end{array}$} & \multicolumn{2}{c|}{$\begin{array}{c}\text { Tidak Terlibat } \\
\text { dalam Pariwisata }\end{array}$} \\
\cline { 3 - 7 } & $\begin{array}{c}\text { Total } \\
\text { Skor }\end{array}$ & Kategori & $\begin{array}{c}\text { Total } \\
\text { Skor }\end{array}$ & Kategori \\
\hline \multicolumn{5}{|c|}{ Komponen 1. Dampak Positif dan Negatif Pariwisata } \\
\hline $\mathbf{1}$ & $\begin{array}{l}\text { Usaha pariwisata milik perempuan akan berperan penting } \\
\text { untuk meningkatkan kesejahteraan masyarakat }\end{array}$ & 298 & Tinggi & 99 & Tinggi \\
\hline $\mathbf{2}$ & $\begin{array}{l}\text { Usaha pariwisata milik perempuan akan memiliki } \\
\text { peran besar di dalam ekonomi masyarakat }\end{array}$ & 297 & Tinggi & 94 & Sedang \\
\hline $\mathbf{3}$ & $\begin{array}{l}\text { Usaha pariwisata milik perempuan akan } \\
\text { meningkatkan standar hidup masyarakat }\end{array}$ & 297 & Tinggi & 92 & Sedang \\
\hline
\end{tabular}




\begin{tabular}{|c|c|c|c|c|c|}
\hline 4 & $\begin{array}{l}\text { Usaha pariwisata milik perempuan akan menjadi } \\
\text { sumber daya yang penting bagi masyarakat }\end{array}$ & 297 & Tinggi & 92 & Sedang \\
\hline 5 & $\begin{array}{l}\text { Pendirian usaha pariwisata milik perempuan akan } \\
\text { mendorong kepariwisataan di Desa Ekowisata Pancoh }\end{array}$ & 303 & $\begin{array}{l}\text { Sangat } \\
\text { Tinggi }\end{array}$ & 97 & Sedang \\
\hline 6 & $\begin{array}{l}\text { Usaha pariwisata milik perempuan akan membantu } \\
\text { melestarikan kebudayaan masyarakat Pancoh }\end{array}$ & 303 & $\begin{array}{l}\text { Sangat } \\
\text { Tinggi }\end{array}$ & 96 & Tinggi \\
\hline 7 & $\begin{array}{l}\text { Usaha pariwisata milik perempuan akan meningkatkan } \\
\text { pemahaman tentang kebudayaan masyarakat Pancoh }\end{array}$ & 302 & Tinggi & 96 & Tinggi \\
\hline 8 & $\begin{array}{l}\text { Usaha pariwisata milik perempuan akan menyediakan } \\
\text { lapangan pekerjaan bagi masyarakat Pancoh }\end{array}$ & 300 & Tinggi & 94 & Sedang \\
\hline 9 & $\begin{array}{l}\text { Usaha pariwisata milik perempuan akan memberikan } \\
\text { dampak negatif pada kebiasaan hidup sehari-hari masyarakat }\end{array}$ & 159 & Rendah & 75 & Sedang \\
\hline 10 & $\begin{array}{l}\text { Usaha pariwisata milik perempuan akan mengganggu } \\
\text { kedamaian di Desa Ekowisata Pancoh }\end{array}$ & 142 & Rendah & 65 & Rendah \\
\hline 11 & $\begin{array}{l}\text { Usaha pariwisata milik perempuan akan } \\
\text { mengganggu kehidupan keluarga }\end{array}$ & 136 & Rendah & 70 & Rendah \\
\hline 12 & $\begin{array}{l}\text { Pendirian usaha pariwisata milik perempuan akan } \\
\text { memecah belah masyarakat Desa Ekowisata Pancoh }\end{array}$ & 127 & $\begin{array}{l}\text { Sangat } \\
\text { Rendah }\end{array}$ & 73 & Sedang \\
\hline 13 & $\begin{array}{l}\text { Usaha pariwisata milik perempuan akan } \\
\text { mengurangi intensitas perempuan dalam } \\
\text { mendukung kebudayaan tradisonal di Desa } \\
\text { Ekowisata Pancoh seperti seni shalawatan, seni } \\
\text { karawitan, wiwit, kenduri, nyadran, dan mitoni }\end{array}$ & 135 & Rendah & 69 & Rendah \\
\hline \multicolumn{6}{|c|}{ Komponen 2. Peningkatan Pariwisata } \\
\hline 14 & $\begin{array}{l}\text { Usaha pariwisata milik perempuan akan } \\
\text { meningkatkan ragam usaha barang dan jasa } \\
\text { pariwisata di Desa Ekowisata Pancoh }\end{array}$ & 288 & Tinggi & 104 & Tinggi \\
\hline \multicolumn{6}{|c|}{ Komponen 3. Peningkatan Ekonomi } \\
\hline 15 & $\begin{array}{l}\text { Usaha pariwisata milik perempuan akan menambah } \\
\text { pendapatan bagi para rumah tangga }\end{array}$ & 298 & Tinggi & 100 & Tinggi \\
\hline 16 & $\begin{array}{l}\text { Usaha pariwisata milik perempuan akan } \\
\text { menambah pendapatan bagi masyarakat desa }\end{array}$ & 290 & Tinggi & 90 & Sedang \\
\hline \multicolumn{6}{|c|}{ Komponen 4. Peningkatan Kapasitas } \\
\hline 17 & $\begin{array}{l}\text { Usaha pariwisata milik perempuan akan meningkatkan } \\
\text { pendidikan para perempuan di Desa Ekowisata Pancoh }\end{array}$ & 293 & Tinggi & 90 & Sedang \\
\hline 18 & $\begin{array}{l}\text { Menurut saya peningkatkan pendidikan perempuan } \\
\text { akan menjadi hal yang baik untuk masyarakat }\end{array}$ & 297 & Tinggi & 101 & Tinggi \\
\hline 19 & $\begin{array}{l}\text { Usaha pariwisata milik perempuan akan meningkatkan } \\
\text { keterampilan perempuan di Desa Ekowisata Pancoh }\end{array}$ & 285 & Tinggi & 95 & Sedang \\
\hline 20 & $\begin{array}{l}\text { Menurut saya peningkatkan keterampilan perempuan } \\
\text { akan menjadi hal yang baik untuk masyarakat }\end{array}$ & 304 & $\begin{array}{l}\text { Sangat } \\
\text { Tinggi } \\
\end{array}$ & 103 & Tinggi \\
\hline \multicolumn{6}{|c|}{ Komponen 5. Struktur Masyarakat } \\
\hline 21 & $\begin{array}{l}\text { Usaha pariwisata milik perempuan akan mengganggu } \\
\text { struktur sosial masyarakat di Desa Ekowisata Pancoh }\end{array}$ & 139 & Rendah & 78 & Sedang \\
\hline
\end{tabular}




\begin{tabular}{|c|c|c|c|c|c|}
\hline \multicolumn{6}{|c|}{ Komponen 6. Kontak Wisatawan } \\
\hline 22 & $\begin{array}{l}\text { Usaha pariwisata milik perempuan akan } \\
\text { mengakibatkan interaksi yang berlebihan antara } \\
\text { perempuan Pancoh dengan wisatawan asing }\end{array}$ & 138 & Rendah & 61 & Rendah \\
\hline
\end{tabular}

Tabel 4. Rata-Rata Sikap Warga Desa Ekowisata Pancoh terhadap Partisipasi Perempuan Pemilik Usaha Pariwisata Berdasarkan Pengukuran WOOTB

\begin{tabular}{|c|l|c|c|c|c|}
\hline \multirow{2}{*}{ No } & \multirow{2}{*}{ Komponen } & \multicolumn{2}{c|}{ Terlibat } & \multicolumn{2}{c|}{ Tidak Terlibat } \\
\cline { 3 - 6 } & & Rata-Rata & Kategori & Rata-Rata & Kategori \\
\hline \multirow{2}{*}{1} & Dampak Positif Pariwisata & 299,6 & Tinggi & 95 & Sedang \\
\cline { 2 - 6 } & Dampak Negatif Pariwisata & 139,8 & Rendah & 70,4 & Rendah \\
\hline 2 & Peningkatan Pariwisata & 288 & Tinggi & 104 & Tinggi \\
\hline 3 & Peningkatan Ekonomi & 294 & Tinggi & 95 & Sedang \\
\hline 4 & Peningkatan Kapasitas & 294.75 & Tinggi & 97.25 & Tinggi \\
\hline 5 & Struktur Masyarakat & 139 & Rendah & 78 & Sedang \\
\hline 6 & Kontak Wisatawan & 138 & Rendah & 61 & Rendah \\
\hline
\end{tabular}

Sikap kedua warga terhadap komponen peningkatan ekonomi menghasilkan ratarata yang berbeda. Sikap warga terlibat dalam komponen ini memiliki rata-rata dengan kategori tinggi, yaitu 294. Berbeda dengan warga yang tidak terlibat, komponen peningkatan ekonomi memiliki rata-rata dengan kategori sedang, yaitu 95. Komponen peningkatan ekonomi terukur pada dua item pernyataan, yaitu "Usaha pariwisata milik perempuan akan menambah pendapatan bagi para ibu rumah tangga" dan "Usaha pariwisata milik perempuan akan menambah pendapatan bagi warga desa". Apabila melihat penelitian Beedle (2011:105), komponen peningkatan ekonomi memiliki persentase yang tinggi. Hal tersebut mengindikasikan bahwa sikap warga terlibat dalam penelitian ini dengan penelitian yang dilakukan oleh Beedle (2011:116) terhadap komponen peningkatan ekonomi bersikap mendukung. Selaras dengan penelitian yang dilakukan oleh Casellas dan Holcomb (2001:148) dan McKenzie Gentry (2007:480) yang menunjukkan bahwa usaha pariwisata milik perempuan akan menambah lapangan pekerjaan bagi warga, terkhusus perempuan dan meningkatkan pendapatan rumah tangga. Akan tetapi, penelitian yang dilakukan oleh Mason dan Chayne (2000) menunjukkan persamaan dengan hasil pada warga yang tidak terlibat dalam kegiatan pariwisata. Penelitian Mason dan Chayne (2000: 402-403) membuktikan bahwa terdapat variasi jawaban warga dalam memandang pengembangan pariwisata akan berdampak pada peningkatan lapangan pekerjaan bagi warga. Kemudian kategori sedang yang terlihat dari ratarata warga yang tidak terlibat dalam penelitian ini menunjukkan adanya variasi jawaban warga dalam menyetujui, tidak memihak, dan tidak menyetujui terhadap komponen peningkatan ekonomi.

Perbedaan lain ditunjukkan pula oleh komponen struktur masyarakat. Komponen tesebut diukur melalui satu item pernyataan tentang "Usaha pariwisata milik perempuan akan mengganggu struktur sosial warga di Desa Ekowisata Pancoh". Melalui pernyataan tersebut, sikap warga terlibat, memperlihatkan hasil rata-rata dengan kategori rendah, yaitu 138 dan warga yang tidak terlibat menunjukkan rata-rata dengan kategori sedang, yaitu 78 . 
Hasil penelitian Beedle (2011) menunjukkan bahwa mayoritas warga menyetujui bahwa usaha pariwisata milik perempuan akan mengganggu struktur sosial. Hal itu menunjukkan bahwa hasil sikap warga terlibat dalam penelitian ini berbeda dengan hasil penelitian Beedle (2011). Apabila melihat sikap warga yang tidak terlibat dalam kegiatan pariwisata, hasil menunjukkan bahwa adanya ragam jawaban warga dalam menyetujui, tidak memihak, dan tidak menyetujui terhadap pernyataan pada komponen struktur masyarakat.

\section{Kesimpulan dan Rekomendasi}

\subsection{Kesimpulan}

Berdasarkan hasil penyebaran kuesioner dan pengolahan data, dapat diketahui masing-masing perspektif sikap warga yang terlibat dan tidak terlibat dalam kegiatan pariwisata berdasarkan enam komponen pengukuran Women Owned and Operated Tourism Businesses (WOOTB). Dari adanya penelitian ini, terdapat pembuktian bahwa terdapat perbedaan sikap warga yang terlibat dalam kegiatan pariwisata dan sikap warga yang tidak terlibat dalam kegiatan pariwisata di Desa Ekowisata Pancoh. Perbedaan itu terletak pada komponen dampak positif pariwisata, komponen peningkatan ekonomi, dan komponen Melalui pengukuran dan komponen struktur masyarakat. Sebaliknya, terdapat persamaan pula antara sikap warga terlibat dan tidak terlibat dalam kegiatan pariwisata di Desa Ekowisata Pancoh. Persamaan tersebut terlihat dari komponen peningkatan pariwisata dan komponen peningkatan kapasitas yang menunjukkan bahwa rata-rata kedua warga menunjukkan kategori tinggi. Selain itu, pada komponen kontak wisatawan dan komponen dampak negatif pariwisata, sikap kedua warga menunjukkan rata-rata dengan kategori rendah.

\subsection{Rekomendasi}

Berdasarkan penelitian ini, penulis melihat adanya kemungkinan sikap warga yang berbeda pada masa mendatang dalam melihat partisipasi perempuan pemilik usaha pariwisata. Hal tersebut didasari penelitian mengenai irritation index yang dilakukan oleh Doxey (1975) bahwa akan adanya kemungkinan perbedaan perspektif masyarakat dalam waktu-waktu tertentu atau yang akan datang.
Desa Ekowisata Pancoh merupakan salah satu desa wisata berkembang di Daerah Istimewa Yogyakarta. Hal itu ditunjukkan dari kenaikan jumlah wisatawan yang melonjak pada tahun 2016. Kondisi ini berkaitan dengan penelitian yang dilakukan oleh Buttler (1980) mengenai destination life cycle. Oleh karena itu, diharapkan adanya penelitian mengenai sikap warga lokal terhadap partisipasi perempuan pemilik usaha pariwisata di tahap destination life cycle yang berbeda dari penelitian ini.

Penelitian yang membahas tentang perbedaan sikap warga terhadap partisipasi perempuan pemilik usaha pariwisata berdasarkan perspektif responden laki-laki dan perempuan dianggap perlu untuk diteliti. Hal itu dikarenakan penelitian Beedle (2011) memperlihatkan adanya signifikansi perbedaan jawaban antara responden laki-laki dengan perempuan.

Penelitian ini merupakan penelitian kuantitatif dan menggunakan skala likert untuk mengukur sikap. Maka, penelitian ini terbatas hanya pada proses generalisasi masing-masing jawaban responden dan tidak cukup untuk menggali data lebih dalam. Oleh karena itu, penulis merasa perlunya penelitian kualitatif yang membahas tentang sikap warga terhadap partisipasi perempuan pemilik usaha pariwisata.

\section{Referensi}

Beedle, J. 2011. "Exploring Resident Attitudes Toward Women Owned and Operated Tourism Businesses". Tesis. The United States of America: South Carolina University.

Bungin, B. 2005. Metodologi Penelitian Kuantitatif: Komunikasi, Ekonomi,

dan Kebijakan Publik Serta Ilmu-Ilmu Sosial Lainnya. Jakarta: Kencana.

Casellas, A dan Holcomb, B. 2001. "Gender, tourism and development in Latin America”. Dalam Y. Aspotolopoulus, S Sonmez, dan D.J. Timothy (Ed.). Women as producers and consumers of tourism developing region. Westport, CT: Praeger Publisher. 235-247.

Chant, S. 1997. "Gender and Tourism Employment in Mexico and the Philliphines". Dalam M. Thea Sinclair (ed). Gender, Work, and Tourism. London: Routledge. 120-179.

Jeffrey, P. 2005. "Perceptions and Attitudes of Individuals. Organizational Behavior in Health 
Care". Dalam N.Borkowski (Ed). Book of the Year Awards: The Most Valuable Texts of 2005, as chosen by AJN's panel of judges. New York: Jones \& Barlett Publishing. 51-57.

Mason, P. and Chayne, J. 2000. "Resident's Attitudes to Proposed Tourism Development". Annals of Tourism Research, Vol. 27. 391-411.

McKenzie-Gentry, K. 2007. "Belizean women and tourism work: Opportunity or impediment?" Annals of Tourism Research, Vol. 34. 477-496.

Mohanty, K. and Rout, H.B. 2015. "Empowering Women through Tourism Development”. Odisha Review. 85-89.

Scheyvens, R. 1999. "Ecotourism and The Empowerment for Local Communities". Tourism Management Vol. 20. 245-249.

Scheyvens, R. 2000. “Promoting Women's Empowerment through Involvement in Ecotourism: Experiences from the thirdworld". Journal of Sustainable Tourism, 235-249.
Scheyvens, R. 2007. "Ecotourism and Gender Issues. Dalam James Higham (Ed.)". Critical Issues In Ecotourism. Oxford: Butterwourth Heinemann, $185-213$.

Sugiyono. 2011. Metode Penelitian Kuantitatif dan Kulitatif dan $R \& D$. Bandung: Alfabeta.

Sumarsono, S, 2004. Metode Riset Sumber Daya Manusia. Yogyakarta: Graha Ilmu.

Umar, H. 2001. Riset Sumber Daya Manusia dalam Organisasi. Jakarta: Gramedia Pustaka Utama.

UNWTO. 2008. "Empowering Women through Tourism".

http://forimmediaterelease.net/pm/1285.html.Diakses pada 4 Maret 2017.

UNWTO. 2011. "Global Report on Women in Tourism, 2010".

http://www2.unwto.org/sites/all/files/pdf/folleto_global report.pdf. Diakses pada 29 Maret 2017. 